\title{
Comparison between Three Out-of-Sequence Thrusts from Japan and Alaska: Implications for Nankai Drilling Targets from the Rock Record
}

by Christie D. Rowe

Increasing recognition has been given to the importance of thrust faults of the "out-of-sequence" geometry as part of the seismogenic plate boundary at subduction zones. The "Good Friday Earthquake” (Prince William Sound, Alaska, 1964) produced a significant tsunami and substantial uplift of a few islands inboard of the trench. Plafker (1972) suggested this could be explained if the rupture propagated up the subduction plate boundary and reached the seafloor by slip on a higher angle splay fault, or out-of-sequence thrust (OOST). Similar tsunami generation mechanisms have been suggested for the December 2004 Sumatra earthquake and tsunami for the area directly offshore Banda Aceh (Simon Day and Steven Ward, personal communications). A largescale OOST is a primary drilling target of the planned Nankai riser drilling project (Kimura et al., 2003).

The Nobeoka Thrust in the Shimanto Complex (Kyushu Island, Japan), very well described by Kondo et al. (2005) and Okamoto et al. (2006), is an excellent locality to study OOSTs. The Nobeoka Thrust juxtaposes two belts of the Shimanto Complex-accreted rocks with a substantial thermal gap $\left(\sim 70^{\circ} \mathrm{C}\right)$, suggesting total throw is $8.6-14.4 \mathrm{~km}$ (Kondo et al., 2005). The hanging wall and footwall are comprised of marine sedimentary rocks of Eocene age. Metamorphism of the hanging wall includes ductile deformation of quartz overprinting earlier brittle structures. The footwall contains only evidence of brittle deformation, further emphasizing the thermal gap. The hanging wall damage zone is thin, crowned by a pseudotachylyte-bearing fault surface only a few meters above the main contact. The fault core is comprised of about $10-20 \mathrm{~cm}$ of dense, subtly foliated cataclasite (A. Yamaguchi, personal communication).

The Uganik Thrust of the Kodiak Accretionary Complex (Afognak Island, Alaska) exhibits remarkable similarity to the Nobeoka Thrust. The thermal gap is approximately $30^{\circ} \mathrm{C}-50^{\circ} \mathrm{C}$ (C. Rowe, J. Hower, and O. Beyssac; unpublished data). The hanging wall is early- to mid-Cretaceous Uyak Complex, comprised of a greenstone-argillite-chert mélange with rare ductile overprinting of brittle structures (Byrne, 1985). The footwall (Kodiak Formation) is black slate and sandstone with a strong characteristic planar flaggy cleavage which is overprinted by tight folding and cleavage-parallel shear fabrics formed during subduction (Sample, 1986). The hanging wall exhibits a highly deformed, stretched, folded damage zone within 1-2 $\mathrm{m}$ of the fault. Mechanisms of deformation include both ductile and granular flow. The fault core is extremely narrow, about $0.5 \mathrm{~m}$ of intensely veined S/C cataclasites. The footwall contains several densely veined subsidiary shear zones $0.5-2 \mathrm{~m}$ wide which have experienced many more episodes of brittle deformation than the surrounding footwall rocks. The concentration of quartz veins is elevated to $10-50$ percent above background in these zones. These subsidiary shear zones persist for approximately $85 \mathrm{~m}$ below the Uganik Thrust, decreasing in size and frequency with distance from the thrust surface.

The Isthmus Bay Fault is a small offset (tens to hundreds of meters) thrust fault within the Ghost Rocks Formation (a mélange complex) of Kodiak Island, Alaska. Although the hanging wall and footwall of the fault are indistinguishable in the conditions of maximum burial $-225^{\circ} \mathrm{C}-250^{\circ} \mathrm{C} ; 280$ $320 \mathrm{MPa}$ (Vrolijk et al., 1988) — the fault-filling veins formed at significantly shallower conditions $\left(140^{\circ} \mathrm{C}\right.$; C. Rowe, unpublished data), suggesting that fault activation followed a period of exhumation. The hanging wall massive sandstone is cut by steeply dipping quartz and calcite veins, possibly related to rupture of the thrust. The footwall is comprised of stratally disrupted turbidites, which are cut by the thrust at a high angle to the fabric. The footwall damage zone is identifiable by a dense network of quartz and calcite veins, and occasional small volumes of vein-supported hydraulic breccias. This zone was observed about $15 \mathrm{~m}$ structurally below the fault. The fault core is a thick $(8-13 \mathrm{~cm})$ multiply cemented breccia; sandstone breccia is cemented by calcite, which was rebrecciated and cemented by quartz. This fault core suggests strong coupling between brittle deformation and substantial fluid flow in faults of the shallow portion of the accretionary prism.

All three OOSTs display extreme asymmetry, with the footwall damage zones two orders of magnitude thicker than the hanging wall damage zones. Evidence of substantial hydrofracture and veining are pervasive in the footwall damage zone and nearly absent from the hanging wall damage zone. This is true when the hanging wall is measurably higher metamorphic grade (Nobeoka Thrust and Uganik Thrust) and when the hanging wall and footwall are of the same grade (Isthmus Bay Thrust). In the case of the deeper, greater offset OOSTs (Nobeoka and Uganik), the fault core itself is dense cataclasite and unlikely to act as a conduit to up-dip fluid flow. However, the shallower OOST (Isthmus Bay) contains a fault core dominated by veins and hydrofracture brecciation. Therefore, it is possible that at 
shallower structural levels, the fault core itself may be the primary conduit for up-dip fluid advection.

When OOSTs are seismically imaged, a strong negative polarity reflector is usually used to identify the fault. This is most likely caused by the presence of aqueous fluids in or near the fault. In the case of these three ancient OOSTs, the most likely structural reservoir for fluids is the highly fractured and veined footwall damage zone. This imaged area is structurally below the actual fault core and below the measured thermal gap where most offset must necessarily occur. As a drilling target, it is important to search for the core of seismogenic OOST structurally above the imaged fault.

\section{References}

Byrne, T., 1985. The Uyak Complex: A brittle-ductile shear zone. GSA Abstracts with Programs, 19(6):440.

Kimura, G., Tobin, H., and Group, N.W., 2003. NanTroSEIZE: The Nankai Trough Seismogenic Zone Experiment Complex Drilling Project. Socorro, NM (New Mexico Tech), 33.

Kondo, H., Kimura, G., Masago, H., Ohmori-Ikehara, K., Kitamura, Y., Ikesawa, E., Sakaguchi, A., and Okamoto, S., 2005. Deformation and fluid flow of a major out-of-sequence thrust located at seismogenic depth in an accretionary complex: Nobeoka Thrust in the Shimanto Belt, Kyushu, Japan. Tectonics, 24(6):TC6008, doi:10.1029/2004TC001655.

Okamoto, S., Kimura, G., Takizawa, S., and Yamaguchi, H., 2006. Earthquake fault rock indicating a coupled lubrication mechanism. e-Earth, 1:23-28.

Plafker, G., 1972. Alaskan earthquake of 1964 and the Chilean earthquake of 1960: Implications for arc tectonics. J. Geophys. Res., 77:901-925.

Sample, J.C., 1986. Structure, Tectonics, and Sedimentology of the Kodiak Formation, Kodiak and Adjacent Islands, Alaska. University of California - Santa Cruz, Calif. (University of California - Santa Cruz), 156 pp.

Vrolijk, P., Myers, G., and Moore, J.C., 1988. Warm fluid migration along tectonic melanges in the Kodiak accretionary complex, Alaska. J. Geophys. Res., 93:10313-10324.

\section{Author}

Christie D. Rowe, Earth \& Planetary Science, University of California, Santa Cruz, 1156 High Street, Santa Cruz, Calif. 95064, U.S.A., e-mail: crowe@pmc.ucsc.edu. 